\title{
The adoption of the materiality concept in social and environmental reporting assurance: a field study approach
}

Article

Accepted Version

Edgley, C. R., Jones, M. J. and Atkins, J. (2015) The adoption of the materiality concept in social and environmental reporting assurance: a field study approach. The British Accounting Review, 47 (1). pp. 1-18. ISSN 0890-8389 doi: https://doi.org/10.1016/j.bar.2014.11.001 Available at https://centaur.reading.ac.uk/38970/

It is advisable to refer to the publisher's version if you intend to cite from the work. See Guidance on citing.

Published version at: http://www.sciencedirect.com/science/article/pii/S0890838914000729

To link to this article DOI: http://dx.doi.org/10.1016/j.bar.2014.11.001

Publisher: Elsevier

All outputs in CentAUR are protected by Intellectual Property Rights law, including copyright law. Copyright and IPR is retained by the creators or other copyright holders. Terms and conditions for use of this material are defined in the End User Agreement.

www.reading.ac.uk/centaur 
Central Archive at the University of Reading

Reading's research outputs online 


\section{The Adoption of the Materiality Concept in Social and Environmental Reporting Assurance: A Field Study Approach}

This study investigates the logics or values that shape the social and environmental reporting (SER) and SER assurance (SERA) process. The influence of logics is observed through a study of the conceptualisation and operationalisation of the materiality concept by accounting and non-accounting assurors and their assurance statements. We gathered qualitative data from interviews with both accounting and non-accounting assurors. We

analysed the interplay between old and new logics that are shaping materiality as a reporting concept in SER. SER is a rich field in which to study the dynamics of change because it is a voluntary, unregulated, qualitative reporting arena. It has a broad, stakeholder audience, where accounting and non-accounting organisations are in competition. There are three key findings. First, the introduction of a new, stakeholder logic has significantly changed the meaning and role of materiality. Second, a more versatile, performative, social understanding of materiality was portrayed by assurors, with a forward-looking rather than a historic focus. Third, competing logics have encouraged different beliefs about materiality, and practices, to develop. This influenced the way assurors theorised the concept and interpreted outcomes. A patchwork of localised understandings of materiality is developing. Policy implications both in SERA and also in financial audit are explored.

Keywords: Institutional logics; Materiality; Social and Environmental Reporting Assurance (SERA) 


\section{Introduction}

This paper investigates the logics or values that shape the social and environmental reporting assurance (SERA) process conducted by accounting and non-accounting assurors. Nearly 95 percent of the largest 250 companies worldwide issue social and environmental reports (SER), of which 46 percent are independently assured (KPMG, 2011). Moreover, SER is increasingly important to stakeholders and institutional investors (Solomon, 2013). The influence of logics is observed through a study of the conceptualisation and operationalisation of the materiality concept, and assurance reports issued by, accounting and non-accounting assurors. We focus on materiality because it is an iconic reporting concept associated with the fair representation of data. ${ }^{1}$

In financial reporting, materiality is a "cornerstone" concept (Lee, 1984) that determines the importance of an item for information users (FASB, 1975). By law, companies are required to show a true and fair view in their financial statements, but the precise meaning of this term is unclear. Materiality complements this fuzzy requirement. It determines important errors or omissions in data but allows a tolerable degree of flexibility in judgments (Brennan and Gray, 2005).

Our study is concerned with the adoption of materiality as a key reporting principle in SER and SERA. New guidance has extended the concept, beyond financial impacts, to the significant social and environmental impacts of corporate performance for a stakeholder audience (AccountAbility, 2003). Material disclosures might include corporate water and energy usage, $\mathrm{CO} 2$ emissions, the environmental impacts of production, fair trade, employee working conditions, workplace diversity, safety technology or areas of stakeholder activism. Material information helps stakeholders to make effective decisions (AccountAbility, 2006).

This redefinition of materiality raises important research questions about assuror judgements in SERA. Why has a core concept, linked to economic decision-making, been adopted in a new reporting field that places corporate social responsibility at its heart? Is the concept of materiality relevant to SER and if so, how? How is materiality in SER different compared to financial reporting? What rationales underpin the concept? How has materiality been adapted to SER? We seek to address these questions and add to our knowledge about the values that underpin materiality and shape SERA. 
This study draws upon insights from neo-institutional theory and institutional logics. Logics are deep principles that underpin behaviours within institutional fields. They prescribe social "assumptions and values" (Thornton, 2004, p.7) and frame the way individuals make sense of reality. Logics provide a useful lens for investigating changes in ideas and practices (Friedland and Alford, 1991). An analysis of the interplay between logics can explain how and why practices change (Lounsbury, 2008). Further work on logics has been called for, in accounting, to understand the dynamics of change in practices (Lounsbury, 2008).

The operationalisation of accounting materiality has been shaped by two traditional logics: a market logic (for the benefit of shareholders) and a professional logic that underpins financial audit. Its adoption into SER has introduced a new, stakeholder logic into its meaning for the benefit of a wide audience. A logics approach is relevant to our study because SER provides a rich context for analysing the interplay between old and new logics in redefining materiality. First, the unregulated status of SER allows nonaccounting stakeholder organisations (the Global Reporting Initiative (GRI) and AccountAbility) as well as accounting bodies (such as the International Federation of Accountants, IFAC) to provide reporting guidance. Second, both professional accounting and non-accounting firms compete to provide SERA in this voluntary market. Differences in beliefs between these two assuror groups have already been observed (O'Dwyer and Owen, 2005). Third, SER comprises softer, qualitative data and lacks helpful benchmarks, such as net profit, to guide materiality decision-making. SER materiality decisions are more subjective. Fourth, boundaries and relationships between organisations in SER are still in a state of flux (Etzion and Ferraro, 2010).

This new institutional environment creates potential tensions between logics. Materiality is a malleable concept (Edgley, 2014) and assuror beliefs may reflect different logics. Although a stakeholder logic is likely to be common amongst all assurors (because SER operates for a stakeholder audience), we anticipate that points of divergence in logics are likely to be observed between these assuror groups. Hybridlogics may be evolving. The understanding of materiality amongst non-accounting organisations in SER (often from an engineering or consultancy background) is not constrained by professional regulation. Their expertise is in assessing risk from an 
environmental and community perspective. They are influenced by a strong commercial logic in seeking to establish themselves in a new field. Accounting assurors, by contrast, must adhere to professional guidance in their understanding of materiality. They are likely to be blending traditional logics that have shaped accounting materiality with a new stakeholder logic in SER. Their expertise is in assessing financial impacts for shareholders. We suggest that these logics compete and shape understandings of materiality differently. We evaluate the consequences for information users.

This paper has three objectives. First, we examine how assurors make sense of materiality in SER and the extent to which this differs from financial audit materiality. We investigate how assurors have accommodated a new stakeholder logic when traditionally materiality has been structured by a market and professional logic, for shareholders. Second, we examine the adaptation of materiality and beliefs that underpin new practices and technologies. We question whether competing logics encourage variations in practices to develop (Lounsbury, 2008). Third, we explore how assurors theorise materiality as an emerging area of expertise in SER and SERA. We query how competing logics may influence beliefs about the outcome of materiality practices.

Our study used qualitative interview data from both accounting and non-accounting assurors and sources of professional guidance to explore materiality. We focus on assurors because, although management initially make materiality decisions, more independent decisions are made by external assurors (Gray and Manson, 2008). ${ }^{2}$ An interview approach was consistent with calls by O'Dwyer and Owen (2005) and Parker (2005) for more SER fieldwork. Furthermore, Messier, Martinov-Bennie and Eilifsen (2005, p. 184) specifically recommended research that examines materiality decisionmaking in a non-financial context,

"Research is needed to determine what is material and how is it determined when the subject matter of the auditor's report is something other than financial data." Materiality is one of a number of accounting concepts, such as understandability, relevance and faithful representation that have been adopted in SER and SERA but warrants analysis in its own right because it underpins other concepts (FASB, 1980). This paper makes two novel contributions. It is the first paper, to our knowledge, to explore, through interviews, both accounting and non-accounting assuror competing 
beliefs about materiality in SER and SERA. Second, it extends an institutional logics approach to the adoption of accounting materiality into a new location, by examining tensions between old and new logics in the understanding of materiality in SER. It considers the emergence of new hybrid logics that are encouraging variations in practices to develop.

\section{Institutional Logics}

Institutional theory provides a useful framework for investigating new practices and beliefs amongst organisations in key institutional fields (Thornton, 2004; Thornton, Ocasio and Lounsbury, 2012). SER is an institutional reporting field with a strong community, stakeholder focus. Ideas about materiality are changing as they spread from financial reporting into SERA. Competing professional bodies and assuror firms are interpreting the concept in different ways.

Institutional theory has previously focused on the diffusion of ideas amongst organisations, mimetic behaviours and convergence (Tolbert and Zucker, 1983). Newer approaches, referred to as institutional logics, view organisations as more varied. Individuals are likely to be influenced by multiple belief systems or logics (Lounsbury, 2007, p. 289). A logic refers to values that structure decision-making (Lounsbury, 2008). Logics are not rigid, but provide a frame of reference about appropriate behaviours (Suddaby et al., 2009; Thornton et al., 2012). Logics connect material practices with symbolic ideas, working together to form a type of order. Major changes in the behaviours and practices of organisational members draw attention to deep shifts in logics and values (Lounsbury, 2008). A logics approach investigates how concepts change as they spread in an institutional field.

A change in ideas amongst organisations does not necessarily reflect a shift from one, dominant logic to another. Multiple logics can shape actions and behaviours (Lounsbury, 2008). Plural logics can co-exist, fluctuating over time (Dunn and Jones, 2010). Tensions between logics may persist for years (Reay and Hinings, 2005). Competition between logics can create ambiguity and explains why variations in practices develop (Lounsbury, 2008). Where conflicting logics are reconcilable, new hybrid logics may emerge. A competing logic may be absorbed into a dominant logic 
(Suddaby and Greenwood, 2005). Greenwood et al., (2002) highlight the importance of theorising change. This involves identifying the failure of existing practices and the justification of new beliefs (Dacin et al., 2002, p. 48). The value of a logics approach lies in investigating how change is brought about by switching or combining logics and how this affects the interpretation of outcomes (Ezzamel, Robson and Stapleton, 2012).

As a precedent for our study, accounting practices and concepts provide a relevant context for contributing to knowledge about logics and change processes (Lounsbury, 2008). Logics have highlighted tensions between the values that accounting brings to a new context, (for example, in healthcare, between financial and medical care considerations). Logics have been used to analyse resistance to change in practices within organisations (Laughlin, 1991; Laughlin et al., 1994; Broadbent et al, 2001). Where competing logics are incompatible, it may be difficult to resolve tensions (Laughlin et al., 1994). A melding of logics can also produce tensions (Dunn and Jones, 2010).

Drawing on Thornton et al., (2012) and Suddaby et al., (2009), central to our study are three key logics: two old logics that have shaped accounting materiality (a market logic and professional logic) and a new, stakeholder logic that has underpinned its adoption into SER. First, the core logic of the market underpins the accumulation and maintenance of material wealth (Friedland and Alford, 1991; Suddaby et al. 2009). A market rationale has shaped traditional, accounting materiality as a concept designed to protect shareholders from misleading information (Edgley, 2014). The shareholder focus of accounting materiality is crucial to the effective operation of capital markets.

Second, is the logic of professionalism which bridges the logic of the state (government administration) and the market. A professional logic is rooted in the public interest and commerce but independent of both (Suddaby et al., 2009). It is the exclusive right, granted to professional accounting firms by the state, to provide financial audit services. This logic frames professional guidance about financial audit and materiality practices for practitioners. It is reflected in the duty of care that auditors have to shareholders as a group. Breaching this duty of care, may result in litigation (Gray and Manson, 2008). 
Third, the adoption of accounting materiality into SER introduces a new community orientated, stakeholder logic, into its meaning. Social factors, important to stakeholders, can substantially influence institutional change (Lounsbury et al., 2003). A stakeholder logic challenges the ethics of capitalism. It frames ideas about reporting social responsibility practices (Harrison and Wicks, 2010). This extends the focus of reporting, from a narrow financial account, to the non-financial impacts of organisations on society. Stakeholder audiences are diverse, ranging from government and regulatory bodies to opinion leaders (legislators, the press, socially responsible investors and nongovernmental organisations), employees and the public. Opinion leaders look for evidence of the impact of corporate social responsible policies in SER. They have greater trust in company reports that adhere to the stakeholder focused GRI and AccountAbility reporting standards (Dawkins, 2004). Geographic location may also influence stakeholder information needs (Ernst \& Young, 2012).

We mobilise logics, in our study, by examining how a stakeholder logic changes understandings of materiality. There was a strong likelihood that accounting assuror beliefs would be influenced by a professional logic. In making judgements, accounting assuror firms must act in the public interest. They also have to consider their commercial success. Balancing a professional and market logic, from an assuror perspective, where they neither over or under-audit is crucial (Malsch and Gendron, 2013). The two different perspectives (shareholder and assuror) of a market logic on the development of materiality are not mutually exclusive. The commercial success of a firm is linked to a duty to protect shareholders from misleading information. We queried whether accounting assurors retained a traditional understanding of materiality. To what extent did they accept or resist a new, stakeholder logic?

Non-accounting assuror firms, however, are not constrained by a professional logic or regulation. Their expertise is consultancy-related, in the implementation and accreditation of environmental managements systems. They are likely to be influenced by a stakeholder logic because they follow guidance produced by stakeholder organisations, the GRI and AccountAbility. A stakeholder based understanding of materiality considers the significant impacts of a company on the environment for a broad audience. This enhances the accountability of SER and SERA (O'Dwyer and 
Owen, 2005). The expertise of non-accounting assurors lies in the assessment of such impacts. These firms are driven by a consultancy rationale (an aspect of a market logic) because they are establishing a niche role as consultants in the SERA marketplace. They compete with accounting firms and are carving out a market for their own distinct assurance methodology. We queried which logics influenced understandings of materiality amongst this assuror group.

\section{Background and Context}

\subsection{Accounting Materiality}

The influence of logics in our study on SERA is observed through the conceptualization of materiality by assurors. Accounting materiality is a fundamentally important reporting principle that underpins the audit process (Gray and Manson, 2008). It has long been associated with the notion of a tolerable level of error in reporting (Power, 1997). Materiality functions as a threshold that determines significant errors or omissions, relevant to decision-making, for the benefit of shareholders. Materiality thresholds are initially the responsibility of management. Auditors then make independent decisions about materiality in reporting on whether the financial statements offer a true and fair view (DeAngelo, 1981; Beatty, 1989; Turley and Cooper, 1991; Davidson and Neu, 1993).

The concept of materiality in financial audit has been shaped by a market logic (a capitalist rationale). It was introduced into US legislation, by the Securities and Exchange Commission (SEC), after the 1929 Wall Street Crash, to protect investors and restore trust in the markets (Rutherford, 2007). ${ }^{3}$ Since then, definitions have been produced by many professional and legal bodies, in different countries. These definitions do not agree completely but share certain characteristics (Brennan and Gray, 2005). ${ }^{4}$ Materiality is a matter of professional judgement. It operates for the benefit of shareholders although no set of rules can be employed consistently to determine materiality in all circumstances. Materiality judgments are qualitative as well as quantitative and depend crucially on the context of a specific omission or misstatement (Gray and Manson, 2008). 
International Standard on Auditing (ISA) 320 provides guidance for practitioners on materiality (IFAC, 2010). Interestingly, ISA 320 has withdrawn any formal definition of materiality, acknowledging that organisations may define materiality in different ways. Instead, it focuses on its generic characteristics. Items may be material if they could reasonably be expected to influence the economic decisions of users.

Prior research has explored materiality practices and rationales in a variety of contexts. Four key findings are apparent (Messier, Martinov-Bennie and Eilifsen, 2005). First, materiality is a relative concept, contingent upon the nature and context of an item. Second, a strong variable driving auditor materiality judgments is the percentage effect of errors or omissions on net profit after tax (Iskandar and Iselin, 1999). Broad rules of thumb may be used (such as a percentage of a base amount). Errors of more than $10 \%$ of net profit are generally considered material, with under $4 \%$ to $5 \%$ considered immaterial (Brennan and Gray, 2005). Ultimately, however, decisions regarding materiality cannot be made mechanistically (Gray and Manson, 2008).

Third, differences exist between materiality thresholds amongst management, assurors and users because of their different motivations and incentives (Messier, 1983; Krogstad, Ettenson and Shanteau, 1984; Estes and Reames, 1988). ${ }^{5}$ Users often have lower materiality thresholds than management, with assurors somewhere between. Amongst audit firms, factors such as firm size, auditor experience and industry may influence decisions (Carpenter and Dirsmith, 1992; Wright and Wright, 1997).

Fourth, materiality is a vague concept (Gray and Manson, 2008; Power, 1997). No set of rules exists that can be applied in all circumstances and thresholds are not disclosed (Gray and Manson, 2008). Interdisciplinary, critical research has suggested that materiality is a social-behavioural rather than a technical phenomenon (Carpenter, Dirsmith and Gupta, 1994). Brennan and Gray (2005) have described this vagueness about materiality as a best kept secret.

In a nutshell, materiality is a concept for shareholders as a group, for the purpose of financial decision-making. It has been shaped, by a market logic (a shareholder focus) and a professional logic (as a responsibility) to protect investors (Edgley, 2014). A move towards a stakeholder logic in financial reporting was briefly considered in the UK, during the Company Law Review in the early 2000's (Company Law Review Steering 
Group, 2001). This idea was not pursued. Accounting materiality therefore has maintained an association with financial impacts and a shareholder focus.

\subsection{A new framework for materiality in SER and SERA}

International Auditing Practice Statement (IAPS) 1010 (IFAC, 1998) extended materiality to social and environmental matters in financial reporting. Such issues have become significant to shareholders and should be disclosed where they have a material, financial impact on the financial statements.

The adoption of materiality into SER was driven by quality concerns. With softer data, directors have more flexibility to report information in a self-serving way, or include excessive detail. Materiality has proved appealing as a filter that sifts wheat from chaff (Sustainability, 2004).

Three prominent bodies have played an important role in the adoption of materiality into SER: IFAC and two non-accounting, stakeholder organisations (the GRI and AccountAbility). These bodies provide guidance for companies and assurors. Their definitions of materiality are different and are detailed below in Table 1.

\section{Insert Table 1 here}

IFAC has produced guidance for accounting firms in International Standard on Assurance Engagements (ISAE) 3000, (IFAC, 2010). ISAE 3000 builds on a traditional accounting understanding of materiality as a professional judgment (FEE, 2002). The focus is on the reliability of data and the minimisation of assurance risk. There is flexibility over the scope of the engagement (assurance may be restricted to part of the report) and over the level of assurance, which may be reasonable (higher) or limited (lower). The assurance statement states whether data is fairly stated in all material respects for a specific group of "intended users and their needs" (IFAC, 2010, para. 12). Under ISAE 3000, assurance may be narrow in scope. For example, Cobham plc's assurance report provided by KMPG LLP is limited assurance of "selected energy and carbon performance within specific highlighted data" on the sustainability section of its website. ${ }^{6}$

The GRI provides guidance about materiality for companies and management rather than assurors. The first set of GRI guidelines referred to materiality in traditional accounting terms. By the time the GRI (2002) guidelines were issued, beliefs about 
materiality had changed. Materiality was linked with other notions of Transparency, Completeness and Timeliness (Etzion and Ferraro, 2010) as a cut off point or threshold for important data. The GRI developed a graph technique to help management apply materiality. The horizontal axis plots the significance of an issue's economic, environmental and social impacts and the vertical axis denotes its influence on stakeholder decisions (GRI, 2006).

AccountAbility has produced reporting guidance for both companies and assurors. In the AccountAbility 1000 standards, materiality is portrayed as a stakeholder-orientated concept (AccountAbility, 2003, 2006a). AccountAbility, at the time the interviews were conducted, viewed materiality as a core-reporting concept linked to completeness and responsiveness. Assurors should assess the materiality of the entire report, with no restriction in scope (unlike the accounting guidance, in ISAE 3000).

SER lacks quantitative benchmarks, such as income or net profit to help determine the materiality of an item. Consequently, AccountAbility have designed a qualitative, benchmarking mechanism, in consultation with external stakeholders, known as the fivepart materiality test. The benchmarking criteria include "policy based performance; business, peer-based norms; societal norms; stakeholder concerns; and short-term financial impacts" (Accountability, 2003, p. 4).

Materiality has been redefined in the AccountAbility guidance as "a framework that helps to align strategy, reporting and performance. Businesses need to work out what is material, and articulate this in credible ways in order to drive learning and innovation" (AccountAbility, 2006a, p.5). AccountAbility have distanced materiality in SER from old accounting logics, "traditional assessments of financial materiality take an overly myopic view of what drives business performance" (AccountAbility, 2006a, p. 14).

In summary, SER provides a flexible field that allows new beliefs and practices about materiality to develop. Key stakeholder groups (socially responsible investors and opinion leaders) expect a different rationale to underpin materiality, beyond financial impacts. The mining industry, a heavily polluting sector, has been encouraged by its stakeholders to assess its impact on local communities (Kyte, 2007). Other issues considered material to stakeholder groups include: greenhouse gas emissions; water and 
energy usage; waste levels and management; hazardous spills; biodiversity; working conditions; human rights; diversity; staff benefits and health and safety matters. ${ }^{7}$

In redefining materiality in SER, old and new logics are at play. In contrast to IFAC's traditional portrayal, the GRI and AccountAbility have not just borrowed, but have reinvented materiality to suit the needs of a broader stakeholder audience.

\subsection{Prior scholarship on materiality in SER and SERA}

There has only been limited research into materiality in SER and SERA. Deegan and Rankin (1997) observed that materiality is relevant to the presentation and disclosure of SER data for users. O'Dwyer (2002) emphasised that CSR is particularly vulnerable to management capture. Management can hide behind a narrow accounting understanding of materiality, only considering financial impacts, to avoid disclosures (Solomon and Edgley, 2008).

Accounting assurors have maintained a traditional, accounting understanding of materiality in SER. O'Dwyer and Owen $(2005,2007)$, in their content analysis of SERA statements, found that accounting assurors potentially failed to consider materiality from a stakeholder perspective. Chiang and Northcott (2012) interviewed financial auditors in New Zealand about their assurance practices. Interviewees interpreted materiality in SER in a traditional way, focusing on financial impacts and ignoring aspects of environmental matters. To our knowledge, we know of no prior study in Europe that has drawn upon logics to analyse the views of both accounting and non-accounting assurors about materiality. As significant differences have been noted in the content of the assurance report produced by these two assurors groups (O’Dwyer and Owen, 2005), a logics approach helps to explore why variations in their understandings of materiality and practices are arising. We probe whether accounting assurors are influenced by traditional shareholder and professional logics that have framed accounting materiality. We consider whether this competes with the stakeholder and commercial logics that may influence non-accounting assurors. The focus of the latter group may be on broader environmental rather than financial/legal liabilities and business behaviours. 


\section{Methods}

To investigate materiality in SER and SERA, we collected qualitative data from twenty interviews with SER assurors (12 with non-accounting UK assuror organisations and 8 with accounting assurors from the Big 4 accounting firms, including one European office, over a two-year period, ending in 2007). Amongst accounting assurors, at the time the interviews were conducted, it was mainly the Big 4 accounting firms that operated in this area (the resource implications precluded smaller firms from competing). We conducted interviews with senior SERA managers and partners from each of the Big 4 firms. We also interviewed individuals at senior management level within all the prominent non-accounting assuror firms in the UK. ${ }^{8}$

Prior research has identified a significant difference in approach between accounting and non-accounting assurors (O'Dwyer and Owen, 2005). For accounting firms, SERA has developed as a branch of audit and advisory services. Non-accounting assuror firms are often from an engineering background with assurance services having developed from their core consultancy services. ${ }^{9}$

We adopted an interpretive approach to examining assuror understandings of materiality. This assumes that individuals understand the world differently and multiple beliefs about concepts may exist (Lincoln and Guba, 1985). We examined assuror narratives to identify the extent of consensus or divergence in their conceptualisation of materiality. Measures were taken to ensure the trustworthiness and authenticity of the study (Lincoln and Guba, 1985; Lukka and Modell, 2010). Regarding the plausibility and sufficiency of the interview data, we interviewed all the major firms that provided assurance services for large listed companies and multinationals. The interviewees selected had relevant qualifications, expert knowledge and experience of senior involvement in SERA. None of the accounting assurors had initially embarked on an accounting career. This was typical of the career paths of individuals in this area. They had moved from a science, engineering or legal background into assurance services. ${ }^{10}$ However, they had all undergone assurance training and had extensive experience working for an accounting firm. It was usual practice for accounting assurors to work alongside a financial audit partner on an assurance engagement. 
Two of the three authors conducted the interviews with the help of two experienced research assistants who were also directly involved. In eight of the interviews, more than one interviewer took part. This ensured that responses were followed up but given the experience of all the interviewers, was not essential.

Semi-structured interviews were conducted to allow individuals to express themselves in their own words. Follow up questions were asked where appropriate. General questions about materiality were employed (see Appendix 1) which formed a discrete section within a wider study of SERA. Interviews on materiality ranged from between sixty to eighty minutes. We asked interviewees open-ended questions: about the different sources of guidance; which guidance they preferred to follow and why; their definition and understanding of the role of materiality; how this differs from financial audit; the need, importance and relevance of materiality to SERA; how they have adapted and applied materiality to firm practices; the detailed operationalisation of materiality in SER and SERA; challenges encountered and rationales adopted to resolve challenges; how management interpreted materiality and about stakeholder information needs. Interview questions were drawn from our understanding of financial audit materiality and the SER and SERA literature. Appendix 2 provides information about interviewees. Interviews were recorded and transcribed by a professional third party audio-typist. We obtained additional secondary data sources about materiality from professional guidance. This ensured we had data from two different sources.

The software used to analyse the source data was NVivo. This added rigour and transparency to our analysis. After importing the source data into NVivo, the interview transcripts were discussed by the authors and research assistants. These discussions were recorded and stored in NVivo as memos. At an early stage in our analysis, fundamental differences were apparent between the beliefs of accounting and non-accounting assurors. We grouped the data to distinguish between their responses. We then coded the data to break it up into categories that related back to our research questions and themes (Richards, 2009). Initial codes were developed by the first author in dialogue with the second and third authors. These codes were developed, a priori, from the literature relating to definitions of materiality, sources of guidance followed, beliefs about its role and relevance, practices and user information needs. 
The first and second authors next developed additional descriptive categories to code information to themes that emerged from the data. These inductively derived categories provided deeper insights into factors that explained why different understandings of materiality and practices were emerging. We repeatedly read our data sources to check that our interpretations of connections between data and our coding structure were authentic.

Dialogue was maintained throughout the study between all three authors and consensus about our interpretations of the data was reached at all stages. Once the data had been broken down so that it no longer resembled a series of individual interviews, we reconstructed our findings. We found that our analysis built upon and corroborated themes that had emerged in our early discussions. This added reliability and validity to our analysis.

Through a logics lens, we analysed assuror beliefs about materiality. We identified statements that accepted/rejected or blended old and new logics. Rationales underpinning practices were investigated. We queried how assurors theorised materiality, how new practices were legitimized and whether hybrid logics were emerging.

\section{Results}

\subsection{Assuror understandings of materiality in SER- a stakeholder frame of reference}

We asked assurors about their understanding of materiality. We investigated their beliefs about its relevance to SER and asked how materiality in SERA was different compared to financial audit. Assuror understandings of SER materiality were rooted in a traditional idea of accounting materiality, as a threshold for determining significant omissions or errors in information. It was not, however, a shareholder concept being rolled out into a new field but operated for a broad, stakeholder audience,

"The definition of materiality in SER would be ... an item is material, when, if it is omitted, it affects the stakeholder's or the user's view" (I1-NA). ${ }^{11}$

Users had diverse information needs. Therefore, assurors determined, for each client, which stakeholder groups were most likely to use the report. This framed their judgements about material issues, 
"So we do take into account that materiality is what's material to the reader. We tend to view the reader as depending on the company, as the people who we think are the most likely to read the reports, so usually, as I said, the investors, NGOs, pressure groups if there are any, and sometimes customers" (I7-AA).

Materiality did not just consider financial impacts but extended to a company's nonfinancial performance and social impacts,

"Materiality tends to be defined as whether the organisation has an understanding and is reporting on the significant issues; its environmental impact, its local community impact” (I13-AA).

SER material issues were linked to social risks and matters of public concern. Examples included responsible resource usage, reductions in $\mathrm{C} 02$ emissions, working conditions or factory protests, areas of stakeholder activism or the subject matter of corporate prosecutions (I20-NA). Hazards for a local community were mentioned, such as chemical spills or flaring gas (I15-AA). Some of these issues had direct financial impacts (I18-AA). Others were sustainability/ethical issues, relevant to evaluating performance, but without clear financial impacts. Assuror beliefs about SER materiality reflected a more social understanding of materiality. Interviewees all agreed that the concept of materiality was relevant to SER. It was just as important as materiality in financial audit, if not more so, because it considered the information needs of a broad audience (I18-AA).

\subsection{Changing rationales underpinning the role of materiality and ethics}

We queried why materiality has been adopted into SER and SERA and rationales that underpinned its role. Although retaining its core threshold characteristic, its purpose and context had changed. Accounting materiality has traditionally been associated with financial impacts where auditors have a moral and legal responsibility to protect investors, as a group, from misleading information. ${ }^{12}$ In the softer reporting environment of SER, materiality functioned as a critical, ethical lens. ${ }^{13}$ Non-accounting assurors in particular viewed the concept as a filter for the disclosure of a balanced, meaningful picture about corporate social responsibility.

First, given widespread concerns about SER being bloated, with little value, materiality was a crucial filter to make information meaningful (I18-AA). Data dumping 
or over-disclosure made it difficult to assess performance. In financial audit, companies may also disclose too much and overwhelm readers. The FRC has raised concerns about cluttered reports (FRC, 2011). In a qualitative context, such as SER, reporting nonmaterial data is even more confusing for stakeholders. For example, a large donation by a company to a charity has a beneficial impact on society but its disclosure is not material if it does not inform stakeholders about its core business activities and strategy (AccountAbility, 2006). Materiality was essential to focus attention on environmental and social responsibility issues that mattered to stakeholders (I18-AA).

Second, SER concerned a different, more complex type of data (I13-AA). With softer, qualitative information, directors could easily ignore or gloss over important issues (I15-AA). Materiality addressed concerns about the adequacy of disclosures and omissions (I15-AA, I18-AA). Materiality symbolised telling the whole story about an issue (I15-AA).

Third, materiality considered past performance but more importantly, looked ahead to future significant environmental risks and challenges. This forward-looking aspect of SER materiality was described as an intelligent function and a critical ethical lens for identifying key issues for users (I18-AA). The amount of forward looking information in SER is vast. Disclosures could easily be harnessed to a self-serving management agenda. A shift to a stakeholder logic appeared to be changing materiality's role. It did not just improve the quality of historic data but could critically filter forward-looking information to anticipate important, future issues.

Materiality therefore functioned as a stakeholder-orientated, ethical lens. This new role builds on the way AccountAbility have redefined the concept as a forward looking concept involving judgements about meaningful data and corporate ethicality. It focused on issues that mattered, or could matter in the future, in the interaction and engagement between companies and society.

\subsection{Problems in adapting materiality in SER- the necessity of a stakeholder logic}

Adaptation involves change and uncertainty. How individuals resolve uncertainty can highlight the influence of particular logics. Not surprisingly, given the soft nature of SER, materiality has been a difficult concept to adapt to SERA. We asked assurors about 
this challenge. Problems were attributed to the absence of helpful benchmarks such as net profit to guide decisions about thresholds (I15-AA). It was difficult to determine material items because of the qualitative nature of the data and the varied information needs of users (I14-AA; I16-AA).

A stakeholder logic strongly framed how assurors problematised materiality. Indeed, SER materiality had to build on stakeholder engagement to make it work. In this respect, they were influenced by the AccountAbility guidance. Initially assurors depended on management to identify material disclosures,

"They (clients) have to assign some level of importance or significance to what they're doing, and if they haven't done that, we find it very difficult to verify" (I3NA).

This happens in financial reporting too but the softer nature of SER made materiality decisions more subjective. Assurors took longer to arrive at an informed view about material issues, especially for a new client (I13-AA). The risk of management capture or selective disclosure of information in SER was greater (I15-AA). This echoed the findings of O'Dwyer (2002) and Solomon and Edgley (2008). When asked if this was a problem, one interviewee commented,

"The client must have their own ideas of what is material because they know their business. If they don't have that then there's no point in us sitting here saying, well what do we think because our judgment will be different from yours. That's fundamental, the client must define it and then we have to determine whether we accept it" (I18-AA). ${ }^{14}$

Given the risk of management capture of materiality, evidence that management aligned their understanding to stakeholder needs was crucial,

"If that process (stakeholder engagement) is there and it's documented then we can use that as a way of assuring us, of getting comfort, that all the material issues are being dealt with in the report" (I15-AA).

Assurors assessed management responsiveness to stakeholder information needs in three ways. First, they talked to stakeholder groups directly about material issues (I15-AA; I20-NA). Second, they evaluated the breadth of views that management considered (I16- 
AA). Third, they examined management processes for engagement and minutes of meetings.

Given the scope for possible tension between management and assuror views of materiality, it was agreed that assurance statements should be addressed to stakeholders, and not management (I14-AA). This was consistent with findings that stakeholder engagement in SERA was becoming a mechanism for driving forward more robust, stakeholder inclusive SER (Edgley, Jones and Solomon, 2010). A shift to a stakeholder logic has been fundamentally important in adapting materiality to SERA.

\subsection{Different sources of professional guidance and multiple logics}

There was consensus amongst assurors that materiality should operate for a stakeholder audience. We interpreted this as the influence of a stakeholder logic. However, points of divergence in their beliefs and different logics were apparent when we asked which sources of professional guidance they preferred to follow. ${ }^{15}$ The interviewees recognized that the three main guidance setting bodies have redefined the concept in different ways, relative to their respective organisational objectives,

"There's the GRI...their definition of materiality in the sense of the right topics... AccountAbility 1000 is based more on a fluid and flexible approach, saying 'understand your stakeholders and let us know what have been the significant issues that they raised, or that you are aware of, in running your operations'. Then the second state of materiality is whether the given issues that have been agreed to be reported on are accurate in a sense. That's the one that is discussed in financial reporting" (I13-AA).

Non-accounting assurors followed the stakeholder-orientated AccountAbility and GRI guidance. This assuror group were aware of the existence of accounting guidance on materiality but its "disciplined and objective" approach was considered narrow (I6-NA). I6-NA illustrated this, with an example of a material spillage of a dangerous toxin. An accounting assurance approach (following ISAE 3000) would focus on the accurate, reliable reporting of the issue, relative to financial and industry benchmarks. An approach following the AccountAbility guidance, would assess the origin of the problem (contaminated land may have been purchased unknowingly) and would evaluate the issue 
as an environmental liability (I6-NA). We interpreted this as acceptance of a strong, stakeholder logic by non-accounting assurors, with a focus on community impacts. This acknowledged the existence of, but resisted a narrower shareholder focus and professional logic (emphasising accuracy in reporting for an investment community).

Accounting assurors, on the other hand, were obliged to follow ISAE 3000. Yet, interestingly, they also cherry picked from other guidance (I15-AA). They appeared comfortable with melding old and new logics. For example, they employed new technologies and practices such as the GRI materiality graph or the AccountAbility fivepart test (both depend on stakeholder engagement to identify and rank material issues). They believed materiality should operate for a broad audience of stakeholders (I14-AA) and not just a specific group of intended users (as prescribed by ISAE 3000). This suggested a shift towards a stakeholder logic. However, their beliefs were framed within the accounting guidance and underpinned by a strong, professional logic. They emphasised that materiality judgements should focus on reliability and the minimisation of assurance risk (I14-AA).

All assurors drew attention to the limitations of the guidance. They considered materiality in SER to be an evolving notion,

"I attended an AccountAbility workshop on the materiality principle and there was still so much debate on what it really means" (I5-NA).

Assurors therefore had considerable flexibility in their interpretation of the concept. This also happens in financial audit but there was greater latitude in SER.

\subsection{Variations in materiality practices}

The influence of divergent logics was most apparent when we compared assuror practices. Whilst all assurors agreed that materiality should operate for stakeholders, competing, hybrid-logics appeared to be guiding its operationalisation amongst the two assuror groups. For non-accounting assurors, objectives and practices focused on identifying material issues and narratives about the management of their social impacts. This approach was considered more useful for readers. For accounting assurors, materiality was directed towards testing the effectiveness of systems for recording non- 
financial data and the reliability of the report for users. This was a more cautious, disciplined approach focused on the accuracy of the report content.

\subsubsection{Non-accounting assurors}

Non-accounting assurors, as a group, favoured an issue-focused approach to material practices. The objective was to check that management had selected the right topics for disclosure,

"In SERA, materiality is not really numbers at all, it's more about ...subject, you know” (I4-NA).

One interviewee commented that assurance should focus on material issues because mechanisms did not yet exist to enable readers to interpret numbers or make decisions based on quantitative data,

"With environmental issues, we don't know what to do with the numbers just yet, realistically, if we're honest about it. So actually you need assurance that the company's doing the right thing rather than verification that the figures are right at the moment" (I11-NA).

Above all, stakeholders required meaningful narratives (I4-NA). Materiality practices involved identifying a client's key stakeholder groups and their information needs,

"You know one of the first things that we do is basically identify, we'll certainly double check, who their stakeholders are, who they think they are, who are their key ones and what are the material issues" (I8-NA).

As well as talking to stakeholders, independent data were gathered about significant issues in the public domain, by using mapping techniques, information scans or internet searches, from websites, NGO's and press clippings (I14-AA; I20-NA). Collecting data from different sources ensured that management were not ignoring important issues (I20NA). This assuror group favoured a freer, fluid approach to the operationalisation of materiality, "you couldn't put a series of numbers or guidelines on it" (I20-NA).

They believed that understanding materiality from a stakeholder perspective helped their clients to address problem areas in their strategy and improve future performance (I19-NA). Associating materiality with responsible business behaviours strengthened 
their clients' environmental risk management processes (I3-NA). As one assuror explained,

"it's not just about checking if the numbers are right but how does that help them manage their risks, how do they respond to their stakeholders and are they reporting on their material issues?" (I19-NA).

This added-value in understanding materiality, on the part of the non-accounting assurors, came through very clearly,

"What you're there to do is not just provide the stamp, you're there to add value to the process, to the client's disclosures and the client's management issues. Coming in to look at words and systems and count numbers doesn't exactly switch us on, but it's an important process" (I20-NA).

An emphasis on adding value blurred the boundaries between consultancy and assurance, which has previously been observed by O'Dwyer and Owen (2005). We interpret this as the emergence of a hybrid logic, combining a business case for materiality (underpinned by a consultancy-driven, market rationale) with a stakeholder logic. This was viewed as a situation where everyone wins (I19-NA). Aligning materiality with strategy improved corporate social responsibility with benefits for society (I6-NA).

\subsubsection{Accounting Assurors}

The accounting assurors, as a group, preferred a systems-based approach to materiality. We interpreted this as a dominant, professional logic, underpinning their practices. The emphasis was on assessing the adequacy of a client's systems for gathering data, professionalism and the reliability of the report. Materiality operated on at least two levels, an issue and a data level, with equal importance assigned to both,

"Materiality operates in terms of what are the issues. It could be issues purely in terms of global impact... and there's also materiality around if you get to a number. Well is the number wrong? If it is $10 \%$ adrift, is that significant? And at every level the benchmark is 'what is this information used for' because materiality has to be dealt with in that context" (I18-AA). 
Accounting assurors, in their practices, were prepared to combine the strengths of the AccountAbility standards and ISAE 3000 (an approach now endorsed by the Dutch Accounting Body, Nederlands Instituut van Registeraccountants (NIVRA)), "A small assurance provider or a consultant can say I've done AA1000 and all the issues are in the report so it's materially complete, whereas they haven't looked in detail at the accuracy of the numbers [but] there is no requirement for an accountant under ISAE 3000 to look at whether the report as a whole is complete. So it's one of the reasons I like the combination of the two approaches" (I15-AA).

This assuror continued to explain,

"If you use the AccountAbility five-part materiality test to identify a list of issues, you actually come up with a list of relevant issues not material issues " (I15-AA). ${ }^{16}$ The importance of a two-stage process in materiality judgments was emphasised. First, the relevance of the issue should be considered and then its completeness. The disclosure of an issue could be misleading if problem areas were ignored,

"The problem with materiality is that you can deal with it at a number of levels....take.... a gas company... and Carbon Dioxide emissions, there might be a description of a 'super duper' project they're doing in ...Brunei, as a case study, but all the problems they've got with flaring gas in South America or Colombia or somewhere isn't mentioned. So you've got part of the story and you've got a material omission” (I15-AA).

A systems based approach was essential to assess how clients collected data about nonfinancial indicators such as $\mathrm{CO} 2$ emissions, energy or water usage. Clients often had immature systems for recording non-financial data and relied heavily on external assurance to detect material errors in data (I15-AA).

Formalised practices were apparent. A rule of thumb to assess the materiality of numerical data of between $5 \%$ and $10 \%$, not dissimilar to financial audit, was used. Other analytical procedures were employed such as assessing directional trends, flowcharts and matrices (I14; I15). Accounting assurors understood the traditional technical complexities of mobilizing the materiality concept in consolidating information, within group reports, such as $\mathrm{CO} 2$ emissions (I14-AA) and ranking the importance and 
reliability of items (I14-AA). Materiality judgments were client specific, depending on a unique set of circumstances (I14-AA).

Similar to non-accounting assurors, independent data were gathered from the public domain. Assurors were then able to produce evidence, if needed, to challenge management about material omissions,

"We talk to our clients about issues that we think, based on our analysis, should be in the report. If they [managers] can demonstrate in their stakeholder engagement that an issue is not material, then that's ok but it's very hard if you do a media search, internet search and you get 5 hits on a subject and it's not in the report" (I15-AA).

The majority of accounting assurors (but none of the non-accounting assurors), linked materiality with assurance engagement risk,

"There's a definition of materiality that we as an assurance provider have in delivering our work, so that is what is the risk of misstatement” (I13-AA).

Accounting assurors, consistent with ISAE 3000 (para 12), adopted a risk based approach to materiality decisions, linked to concerns about legal liability,

"Yes I think we (accounting assurors) are more aware of risks and we have deeper pockets. You will not see a multi million claim on a small engineering firm because they know that they will never pay it. So we are more aware about risk and risk management... Sometimes we are jealous that they (non-accounting assurors) do not have these constraints but it's managed very carefully I would say" (I14-AA).

Examples of litigation risk were cited,

"There are some companies, who will remain nameless, who had reserves numbers in their environmental reports (that) their assurance provider signed off. That reserves number proved wrong and the assurance provider may find themselves in court" (I18-AA).

Although none of the accounting assurors were accountants by background, they worked closely with financial audit partners (I14-AA). Their understanding of materiality was strongly influenced by accounting firm culture,

"We are in the accountancy firms and I'm not an accountant by the way but we live under very rigid standards and regulation...based on that long track record, and 
body of knowledge from accountancy...There are certain things in the philosophy of accountants that I think are fairly valuable for this process" (I14-AA).

Their practices suggested a shift towards a stakeholder logic, but this acceptance has been absorbed within a rigorous, professional approach. This again, we interpreted as a hybrid logic. There was a strong concern to minimise assurance risk, with a focus on the reliability and accuracy of data. This contrasted with the commercial approach of the non-accounting assurors.

\subsection{Theorisation and legitimisation of different practices}

Hybrid logics, arising from an interplay between competing logics, appeared to be encouraging variations in assuror practices. For non-accounting assurors a stakeholder logic was melded with a business case or commercial logic for materiality. Materiality could add value for management and stakeholders by improving performance. For accounting assurors, a stakeholder logic has been absorbed within a professional logic. We probed how the different assuror groups theorised and legitimised their different practices. Hybrid logics influenced their interpretation of outcomes, in distinct ways.

Non-accounting assurors were critical of the cautious, professional logic of accounting assurors (which echoed observations made by O'Dwyer and Owen, 2005). Accounting firms were considered to be,

"great with numbers and data but they struggled with the narrative, softer issues such as community, philanthropy, social and ethical issues" (I20-NA).

They over-emphasised the importance of data accuracy,

"Say, carbon dioxide emissions, if you've seen somebody with a financial background go at it, they get really hung up in all the maths and the stuff behind it" (I1-AA).

Accounting assurors were narrower in their construction of materiality. They evaluated materiality against financial benchmarks rather than assessing broader environmental liabilities (I6-NA). Non-accounting assurors legitimised their own softer approach as an alignment of materiality with responsible business management. The value of this outcome lay in identifying, not just material impacts, but areas where behaviours and policies could be improved. This assuror group disclosed recommendations about the 
management of material risks, in the assurance statement, for stakeholders. ${ }^{17}$ Providing advice, visible to readers, about materiality management, emphasised a stakeholder and consultancy-driven market logic. ${ }^{18}$ Making recommendations was viewed as a duty (I20NA).

In contrast, the accounting assurors were critical of the consultancy driven, market logic of non-accounting assurors,

"What I can see with the consultancies, the engineering consultancies, they are rather liberal in their view about mixing advice and giving assurance” (I14-AA).

In focusing on issues and advice, they overlooked the relationship between materiality, evidence and the reliability of data,

"So the implication for the reader might be the whole report is reliable, when they haven 't actually done sufficient work" (I15-AA).

Gathering sufficient evidence about material issues should involve careful planning and a systematic, defensible approach (I7-AA). Accounting firms endorsed the benefits of a professional logic, and a risk based approach to assurance. High-risk clients, with unreliable systems, would not be taken on,

"We can lose as a firm our accreditation. It's very serious for us, risk management and I've never seen it in engineering consultants (I14-AA).

A strong professional logic shaped accounting assuror beliefs about the outcome of materiality in SERA. Its value lay in enhancing the reliability of reports. Recommendations to management were private. The content of accounting assuror statements was formulaic (covering the scope of the engagement, guidance used, work performed and a conclusion) and the value of their work was less visible, for users,

"If you look at the report you will not see, after our work, what changes were in the report and there are sometimes significant changes in the report based on our work. The reader would not see it, and this is the internal value" (I13-AA).

This reinforced an idea of materiality as a secretive matter of professional judgement and expertise, previously observed in financial audit materiality. ${ }^{19}$ 


\section{DISCUSSION}

This section discusses how our paper advances studies in institutional logics in the understanding of SER materiality. We consider the influence of competing logics on assuror behaviours and practices. Several key questions are addressed about the role, and relevance of materiality in SER, compared to financial audit.

\subsection{Institutional logics and materiality in SER}

Following the adoption of materiality into SER, its meaning and practices have changed. Several factors have encouraged changes to take place: first, the malleable nature of the concept lends itself to reinvention (Edgley, 2014); second, the voluntary nature of SER provides a flexible frame of reference for multiple beliefs to develop; third, SER is more subjective; fourth, is the presence of heterogeneous guidance setters and assurors; and fifth, is the introduction of a new stakeholder logic into this field. These factors have provided scope for interplay between logics.

The GRI and AccountAbility adopt the symbolic idea of materiality as a threshold but are drawing on a stakeholder logic to reconstruct the concept in SER. This process of copying an accounting concept and then differentiating it from traditional beliefs, has previously been interpreted as a mechanism for building influence in a new field (Etzion and Ferraro, 2010). Linking materiality with new scientific practices such as the AccountAbility five-part test and graphs, both designed in partnership with stakeholders, has helped to standardise and legitimise new practices. IFAC on the other hand has maintained a more traditional understanding of materiality as a matter of professional judgment.

A mix of old and new logics has influenced assuror practices. Indeed, a hybridisation of logics is encouraging variations in practices between the two assuror groups. Non-accounting assuror firms have identified with a stakeholder logic. We saw evidence of a business case for materiality amongst this group (linking materiality to a consultancy rationale). This melding of a stakeholder and commercial interpretation of materiality reflects the expertise of these firms in providing advice about environmental management systems. The focus of materiality has shifted away from the report, towards improving corporate performance and aligning materiality with strategy. 
For accounting assuror firms, contrasting factors have influenced hybridisation in a different direction. First, the firm itself has technical expertise about traditional accounting materiality. For example, accounting assurors understood the complexities of applying materiality to consolidated reports. They retained a strong shareholder logic where errors in SER data could translate into financial impacts for shareholders. They were influenced by a professional logic, recognising a responsibility to a client and users to carry our assurance practices rigorously. In addition, they sought to produce a professional report, emphasising discipline and accuracy, to minimise exposure to legal liability. Second, a mix of reporting guidance has influenced this assuror group. They have not ignored pressures to shift to a stakeholder logic from a shareholder focus. They viewed information users as a broader group, than ISAE 3000 requires. This openmindedness may result from their broader experience prior to joining an accounting firm and senior partners often networked closely with stakeholder organisations, including AccountAbility. A professional logic was, however, dominant. The focus of materiality was on reducing assurance risk, to the extent that high-risk clients, with unreliable systems for recording data would not be taken on. The emphasis was on the reliability of the client's report and on improving their internal control systems to minimise the risk of a material error arising in data, whilst the wording of the assuror report itself was constrained and formulaic.

Our observations confirm the findings of Carpenter et al., (1994) that materiality is a social-behavioural phenomenon, strongly influenced by a firm's culture and objectives. The way in which the two different assuror groups theorised the concept, particularly its outcomes, reinforced their respective jurisdictional strengths and values. For nonaccounting assurors, a consultancy-orientated rationale, with no concern about legal liability, framed a performative understanding of materiality. The outcome of materiality was theorised as giving visibility, in the assurance report, to areas for improvement in relation to important issues. For accounting assurors, approaches to materiality decisionmaking were structured and systems orientated. The outcome of materiality was viewed as less visible to users (i.e. advice about the management of material issues was not reported in the assurance statement) but an essential difference that accounting-assurors made to the quality of reporting. These conflicting beliefs as to whether opinions about 
material areas for improvement should be visible or invisible in the assurance statement, may explain why O'Dwyer and Owen, (2005) found little evidence of a consideration of materiality from a stakeholder perspective in their content analysis of accounting assuror statements.

With a highly subjective reporting concept, such as materiality, variations in practices and beliefs may create confusion. Users may not recognise that materiality decisions are localised and dependent on a mix of logics. Decisions may differ according to assuror firm culture, the engagement scope, the extent of stakeholder engagement (between management, assurors and stakeholders) and sources of professional guidance. However, interplay between logics that encourages variations in practices has advantages too. Ideas are able to develop freely, unconstructed by regulation and tradition. Over time, this may encourage debate about best practice.

Our findings are also relevant to understanding how an interplay between logics continues to influence the development of SER guidance. Dunn and Jones (2010) observed that plural logics can co-exist, fluctuating over time. Such tensions may persist for years (Reay and Hinings, 2005). For example, initially, the Accountability guidance distanced its beliefs about materiality from the professional logic that underpinned ISAE 3000. The risk averse, disciplined approach of the latter, for intended users, may have seemed too narrow when AccountAbility was promoting SER and SERA for a wide, stakeholder community. The AccountAbility standards were subsequently revised in 2008. The two major changes made (allowing two levels of assurance and formalising assurance engagement acceptance procedures) removed a major point of divergence between the AccountAbility assurance standards and accounting guidance. These changes were underpinned by a professional logic. This shift signaled recognition of how the scope of an assurance engagement affects the context in which assurors make judgements. We interpret this as evidence of a continuing interplay between logics that influences the development of practices.

\subsection{Reflections about materiality - some key questions addressed}

A number of questions about materiality were posed in the introduction. Why has a core concept, linked to economic decision-making, been adopted in a new reporting field 
that places corporate social responsibility at its heart? Is the concept of materiality relevant to SER and if so, how? How is the concept of materiality in SER different to materiality in financial reporting? What rationales underpin the concept? How has materiality been adapted to SER? To conclude our discussion, we address these. Materiality has been adopted in SER because of concerns about the quality of SER in a soft, unregulated arena. Materiality is relevant to SERA because it focuses on data that should be included and filters out clutter. It addresses uncertainty in reporting and social risks. In SER, risks for stakeholders are related to an absence of relevant, reliable information about corporate material impacts. These may affect business strategy, a community, working conditions, wider society, the environment, or climate change.

Materiality in SER is therefore significantly different from materiality in financial audit. Although contingent upon the idea of a threshold, a new stakeholder logic links materiality to social responsibility issues (as opposed to a purely, short term, market logic). It not only considers past data but is a forward looking lens.

The more subjective nature of materiality in SER and SERA makes it susceptible to management capture and a mix of logics underpins the way it is understood by assurors. Therefore, a shift to a stakeholder frame of reference that recognises the value of stakeholder engagement in identifying material issues has been essential to its adaptation in SER. By contrast, in financial audit, close involvement with information users is neither common place or encouraged. Sufficient expertise lies with auditors, but this is not the case in SER.

Our study highlights a strong association, particularly by non-accounting assurors, between materiality and important, ethical issues. Materiality operated as a type of critical ethical lens in checking that disclosures provided a complete story about responsible corporate conduct. This shifts its focus away from accuracy in reporting to the inclusion of key areas of performance. This change in emphasis within materiality in SER and SERA is relevant to understanding why the newly formed Sustainability Accounting Standards Board (SASB) is mapping material issues by industry sector and calling for sector specific materiality and sustainability standards. In an uncertain reporting arena, the idea of material issues by industry is appealing as a standardised template for reporting (Eccles et al., 2012). 
Materiality remains, however, a rather vague concept. This is the case too in financial audit but in SER, this vagueness was accentuated. Our study potentially adds to an understanding of the materiality concept generally. Materiality decision-making in practice could be viewed as a type of patchwork (Law and Mol, 2005). ${ }^{20}$ In SER, judgments about materiality are localised, varying from firm to firm, and context to context. Materiality decisions are the result of negotiation and engagement between assurors, management and key stakeholder groups. Decisions appear rational in their individual locations. However, it is problematic to construct a coherent, clearly defined, understanding of materiality when multiple logics underpin its operationalisation.

\section{Implications and conclusion}

This article presents new evidence about the influence of logics on SERA. An interplay between logics was observed through the conceptualisation and enactment of the materiality concept by accounting and non-accounting assurors. The materiality concept is an essential but problematic concept in the audit process. Following its adoption into SER and SERA, central to our study is the introduction of a new, stakeholder logic into its meaning. We analysed the findings of interviews with assurance providers to explore how changes in beliefs about materiality in SERA have been influenced by an interplay between old and new logics. SER is a rich field in which to explore logics because of its qualitative, subjective nature and the absence of uniform regulation, among competing accounting and non-accounting bodies and firms. The framework of SER is shaping materiality to cope with the demands of softer, uncertain data and diverse user information needs.

Materiality in SER shares a threshold characteristic with accounting materiality but has shifted towards a stakeholder focus, emphasising the social and environmental impacts of corporate non-financial performance and the importance of stakeholder engagement. A key finding of the paper is how tensions between old and new logics have encouraged competing hybrid logics to develop amongst the two assuror groups. Amongst non-accounting assurors, a business case for materiality melds with a stakeholder logic, focusing on corporate performance. Amongst accounting assurors, a stakeholder logic has been absorbed into a professional logic, driven by a liability 
constrained market logic. For non-accounting assurors, materiality was a highly visible concept drawing attention to areas requiring improvement in performance in the assurance statement. For accounting assurors, materiality was invisible, related to the reliability of reports and not referred to in detail in the assurance statement.

Accounting assurors point to a need for materiality decisions to be embedded in a systems-based approach to SERA, based on the traditional strengths of accountants, and a professional logic. They expressed strong concerns about a lack of reliability in SER data produced by weaknesses in controls over non-financial systems. This in turn affected materiality judgments. Managers often relied on assurors to identify material omissions or errors in reported data. A focus on the reliability of the report also aligned materiality with the desire to minimise the risk of litigation. For non-accounting assurors, materiality decisions should be performative rather than normative. Materiality helps companies to improve their SER strategy and performance. This linked materiality with consultancy objectives. These variations in practices and understandings reflect divergent organisational priorities and highlight the extent to which materiality is a social and behavioural phenomenon.

Localised interpretations of materiality are emerging which may be rational in context, but problematical when attempting to create a consistent understanding. This has implications for information users which we highlight below and we also identify areas for future research.

First, an interplay between multiple old and new logics is advantageous, as it encourages the exploration of different aspects of materiality. However, this constrains its usefulness as a screening mechanism. Stakeholders need to understand that hidden factors, such as assuror culture, engagement scope and the extent of stakeholder inclusivity in SER and SERA can influence interpretations of materiality. If such issues are not addressed, this potentially widens an expectations gap between users and assurors. More research could fully address these factors.

Second, there is a need for increased debate and disclosure about materiality in SERA to improve its quality, transparency and consistency. Dialogue should be encouraged between managers, assurors and users regarding best practice. This should strike a balance, for example, between a systems based approach, with an emphasis on 
the reliability of reported information and an approach that considers how disclosures about material issues are aligned to strategy and corporate performance. Both are important.

Third, there is an urgent need for consistent guidance about materiality. The International Accounting Standards Board (IASB) acknowledges that the application of the concept in financial reporting is a major source of disclosure problems. A project to improve guidance in this area could start by undertaking research that looks across jurisdictions and disciplines, both accounting and auditing guidance, case law, academic literature and regulatory guidance (IFRS, 2014). The same applies equally to the concept of materiality in SER and SERA. Research could be conducted by guidance setting bodies into different perspectives held by stakeholder groups. This could investigate factors that are causing uncertainty in reporting and enable a stronger dialogue about materiality to develop. One of the major limitations of the current study is the absence of stakeholder views about materiality. A wider study that looks more closely at stakeholder understandings of materiality and information needs could assist the development of guidance. Further research into the importance of other reporting concepts such as understandability, relevance and faithful representation would also be helpful.

Materiality in SERA is still in its infancy, but developing. Currently, it reflects the evolving nature of this new reporting field. The next stage in its evolution is crucial if a more consensual rather than a patchwork understanding of materiality is to develop. AccountAbility (2013) recently reported that SER materiality is increasingly relevant to effective governance and corporate valuation. This perhaps adds weight to the findings of our study that understandings of materiality are fragmented, underpinned by multiple logics. Certain logics are emphasised at different times in particular contexts. The findings are therefore relevant to future debate about materiality in SER, especially given the emergence of integrated corporate reporting (KPMG, 2010) and calls for sector specific materiality and sustainability reporting standards (Eccles et al., 2012). This again radically changes the context in which materiality decision-making is made.

\section{Acknowledgements}

The authors would like to thank a number of individuals for their assistance and help with the development of this paper. First of all, may we thank our two research assistants Daniel Rodriguez Martin and Sally 
Filson for their extensive help with interviews. May we also thank colleagues who have helpfully provided feedback and suggestions for developing the paper at the EAA Congress in Ljubljana in 2012 and the BAFA conference 2012. We are also grateful to two anonymous reviewers for their helpful insights and suggestions for strengthening the paper. 


\section{Notes}

${ }^{1}$ We are grateful to an anonymous reviewer for suggestions that have strengthened our articulation of the objective of the study.

${ }^{2}$ The concept of independence is central to accounting professional ethics and the quality of financial audit. A more independent professional judgment is reached by parties that are external to a company.

3 "The term "material," when used to qualify a requirement for the furnishing of information as to any subject, limits the information required to those matters as to which an average prudent investor ought reasonably to be informed before purchasing the security registered," (United States Securities and Exchange Commission (SEC), Regulation S-X, 1933).

4 Differences between the International Accounting Standards Board (IASB) and Financial Accounting Standards Board (FASB) definitions are currently being addressed in a joint accounting conceptual framework project. Both Boards' current position is that no general standards of materiality can replace human judgment

${ }^{5}$ Materiality remains controversial. Currently, it is the subject of consultation by the European Securities and Markets Authority (ESMA, 2011). The IASB has also recently made an announcement about undertaking a project about materiality and uncertainty.

${ }^{6}$ http:/www.cobhamsustainability.com/media/20734/Independent2012Limited assurance StatementbyKPMG.pdf

${ }^{7}$ This list can be viewed at http://web.ifac.org/sustainability-framework/impsustainability-performance.

${ }^{8}$ The study is largely UK based. Norms and practices may differ in other countries which may yield fruitful areas for further research.

${ }^{9}$ Such consultancy services would include preparation for, and accreditation under, ISO 14000, the EU Eco-Management and Audit Scheme or other specific projects to improve business sustainability performance and strategy.

${ }^{10}$ For one accounting assuror firm, a science background was a prerequisite for a career path in SERA.

${ }^{11}$ Interview referencing is explained in Appendix 2.

${ }^{12}$ A moral responsibility refers to norms or duties that guide interactions between individuals and is often interwoven within legal or social power structures.

${ }^{13}$ The term ethical lens is used in the sense of arriving at a judgement about ethicality. Sparks and Pan (2009) summarise an ethical judgement as an evaluation of the degree to which behaviour or a course of action is ethical or unethical.

${ }^{14}$ This follows the professional guidance. Both AccountAbility (2006a, p. 50) and the Fédération des Experts Comptables (FEE, 2002, paragraph 27) have both stated that the determination of issues, likely to be material to the long-term success of corporate strategy are the responsibility of the company rather than the assuror.

${ }^{15} \mathrm{We}$ are grateful to an anonymous reviewer for drawing attention to the importance of emphasising this point.

${ }^{16}$ This comment echoed aspects of a long-running debate in the accounting literature on the trade-off between the concepts of relevance and reliability in materiality decisionmaking in financial audit in SFAC 2 (FASB, 1980). 
${ }^{17}$ As an example, one non-accounting assuror firm disclosed in a 2006 assurance statement a recommendation that company $\mathrm{X}$ should continue to strive for alignment to the principles of AA1000 in its future sustainability reporting and assurance, and should update this to reflect feedback from the 2006 stakeholder dialogues. This should both help identify and manage material risks and support value creation.

${ }^{18}$ As an example, illustrating this point, the Bureau Veritas assurance statement for Nestle in 2009, and a visible opinion on materiality, states,

"Building on previous years, the assurance process was designed to understand how Nestlé identifies its material risks and emerging issues in a continually changing environment, and to challenge Nestlé's in its CSV implementation, performance and reporting...Nestlé has further improved clarity in the reporting of its CSV governance, accountability and management structures in its reporting. In particular this has been achieved through additional disclosure over its approach to materiality determination and the newly formed CSV Alignment Board. Looking forward, Nestlé should now demonstrate to stakeholders how these governance mechanisms are used to inspire and empower individual markets towards business decisions aligned with its overall CSV aspirations." (http://www.nestle.com/asset-library/Documents/Creating\%20Shared\%20Value/ About_reporting/BV_statement.pdf)

${ }^{19}$ As an example, the KPMG assurance report on Cairn Energy 2008 is more focused on steps taken and procedures. It is concluded,

"Nothing has come to our attention that causes us to believe that the description of Cairn Energy's adherence to the AA1000APS (2008) principles of inclusivity, materiality and responsiveness, marked with the symbol + in the Report, is not, in all material respects, fairly stated in accordance with the GRI reporting principles for defining report quality."

${ }^{20}$ Law and Mol (2005) use patchwork metaphor to describe, in sociology, how our relationship with material objects in a material culture, is constructed in a social context. Material and social processes are produced together in situ. Localised understandings of materiality emerge. 


\section{References}

AccountAbility (2003) Redefining materiality, AccountAbility, London.

AccountAbility (2006a) The Materiality Report, AccountAbility, London.

AccountAbility (2006b) AA1000 Guidance Note on the Principles of Materiality,

Completeness and Responsiveness as they Relate to the AA1000 Assurance

Standard, AccountAbility, London.

AccountAbility (2008a) AA1000 Assurance Standard, AccountAbility, London.

AccountAbility (2008b) AA 1000 AccountAbility Principles Standard, AccountAbility, London.

AccountAbility (2013) Redefining materiality II. Why it matters, who's involved and

what it means for corporate leaders and boards, AccountAbility, New York.

Beatty, R. P. (1989) Auditor reputation and the pricing of initial public offerings, The Accounting Review, 64 (October), pp. 693-709.

Bernstein, L. (1967) The Concept of Materiality, The Accounting Review, 42, pp. 86-95.

Brennan, N. and Gray, S. (2005) The Impact of Materiality: Accounting's Best Kept Secret, Asian academy of Management Journal of Accounting and Finance, 1, pp. $1-31$.

Broadbent, J., Jacobs, K., and Laughlin, R. (2001). Organisational resistance strategies to unwanted accounting and finance changes: the case of general medical practice in the UK, Accounting, Auditing \& Accountability Journal,14(5), pp. 565-586.

Carpenter, B.W. and Dirsmith, M.W. (1992) Early debt extinguishment transactions and auditor materiality judgments: A bounded materiality perspective, Accounting, Organisations and Society, 17, pp. 709-739.

Carpenter, B.W., Dirsmith, M.W. and Gupta, P.P. (1994) Materiality judgments and audit firm culture: Social-behavioural and political perspectives, Accounting, Organisations and Society, 19, pp. 355-380.

Carruthers, B. (1995) Accounting, ambiguity and the new institutionalism, Accounting, Organizations and Society, 20(4), pp. 313-328. 
Chiang, C. and Northcott D. (2010) Audit Materiality and environmental Matters, The Australian National Centre for Audit \& Assurance Research - 8th Annual Australasian Audit Research Forum, Canberra.

Company Law Steering Group, (2001) Modern Company Law for a Competitive Economy: Final Report (DTI, London,2001).

Davidson, R. A. and D. Neu. (1993) A note on the association between audit firm size and audit quality, Contemporary Accounting Research (Spring) pp. 479-488.

Dacin, M. T., Goodstein, J., and Scott, W. R. (2002). Institutional theory and institutional change: Introduction to the special research forum, Academy of management journal, 45(1), pp. 45-56.

Dawkins, J. (2004) Corporate responsibility: The communication challenge, Journal of Communication Management, 9 (2), pp.108 - 119.

DeAngelo, L. E. (1981) Auditor size and audit quality, Journal of Accounting and Economics, 3, pp.183-199.

Deegan, C. and Rankin, M. (1997) The materiality of environmental information to users of annual reports, Accounting, Auditing and Accountability Journal, 10(40), pp. $562-583$.

Dunn, M. B., and Jones, C. (2010) Institutional logics and institutional pluralism: The contestation of care and science logics in medical education, 1967-2005, Administrative Science Quarterly, 55(1), pp. 114-149.

Eccles, R., Krzus, M., Rogers, J. and Serafeim, G. (2012) The need for sector specific materiality and sustainability standards, Journal of Applied Corporate Finance, 24 (2), pp. 8-14.

Edgley, C., Jones, M. and Solomon, J. (2010) Stakeholder inclusivity in social and environmental report assurance, Accounting, Auditing and Accountability Journal, 23 (4), pp. 532-557.

Edgley, C. (2014) A genealogy of materiality, Critical Perspectives on Accounting. 25(3), pp. 255 - 271 
Ernst \& Young (2012) Managing demanding stakeholders. Building the right relationships in Russia's maturing consumer products market. Ernst \& Young. July 2012.

European Securities and Markets Authority (ESMA) (2011) http://www.esma.europa.eu/content/Consultation-paper-Considerations-materialityfinancial-reporting

Estes, R. and Reames, D. (1988) Effects of personal characteristics on materiality decisions: A multivariate analysis, Accounting and Business Research, 18, pp. 291296.

Etzion, D. and Ferraro, F. (2010) The role of Analogy in the Institutionalization of Sustainability Reporting, Organization Science, 21(5), pp. 1092-1107.

Ezzamel, M., Robson, K. and Stapleton, P. (2012) The logics of budgeting: Theorization and practice variation in the organisational field, Accounting Organisations and Society, 37, 5, pp. 281-303.

FASB (1975) Materiality: Discussion memorandum, Stamford, CT.

FASB (1980) SFAC 2 Concepts Statement No. 2 Qualitative Characteristics of Accounting Information; Issue Date 5/1980.

FASB (2008) Statement of Financial Accounting Concepts No.2, Qualitative Characteristics of Accounting Impacts, first issued, 1980, FASB.

FASB and IASB (2008) Conceptual framework for financial reporting: The objective of financial reporting and qualitative characteristics and constraints of decision useful financial reporting information, Exposure Draft, file reference no. 1570 - 100.

FEE (2002) Providing assurance on sustainability reports, Discussion Paper, Federation des Experts Comptables Europeens, Brussels.

FRC (2011) Cutting Clutter: Combating clutter in annual reports. Financial Reporting Council.

Friedland R., and Alford, R. (1991) Bringing society back in: Symbols, practices and institutional contradictions, in Powell, W. $\mathrm{W}$ and Di Maggio, $\mathrm{P}$ J, The new institutionalism in Organizational analysis, University of Chicago Press, Chicago. 
Global Reporting Initiative (GRI 3) (2000-2006) Sustainability reporting guidelines on economic, environmental and social performance, Global Reporting Initiative, Amsterdam.

Gray, I., and Manson, S. (2008) The Audit Process, $4^{\text {th }}$ edition, Thomson.

Greenwood, R., Suddaby, R., and Hinings, C. R. (2002) Theorizing change: The role of professional associations in the transformation of institutionalized fields, Academy of management journal, 45(1), pp. 58-80.

Harrison, J. and Wicks A. (2010) Stakeholder Theory: The state of the art, Cambridge University Press.

Holstrum, G. L. and W. F. Messier, Jr. (1982) A review and integration of empirical research on materiality, A Journal of Practice and Theory, 2(1), pp. 45-63.

IFAC (1998), Practice statement 1010, IFAC, New York.

IFAC (2008) International Auditing Standards 320, Audit Materiality, IFAC, New York.

IFAC (2010) International Auditing Standards 320, Materiality in planning and performing an audit, IFAC, New York.

IFAC (2010) International Standard on Assurance Engagements 3000, Assurance engagements other than audits or reviews of historical financial information, IFAC, New York.

\section{IFRS (2014) Disclosure Initiative: Materiality}

http://www.ifrs.org/Meetings/MeetingDocs/IASB/2014/March/11B\%20Disclosure \%20Initiative\%20Materiality.docx.pdf (accessed, 27 May, 2014)

Iskandar, T. and Iselin, E. (1999) A review of materiality research, Accounting Forum, 23, pp. 209-239.

KPMG (2010) Carrots and Sticks: promoting transparency and sustainability. KPMG International, UNEP, GRI and University of Stellenbosch Business School.

KPMG (2011) International Survey of Corporate Responsibility Reporting, KPMG International.

Krogstad, J., Ettenson, R. and Shanteau, J. (1984) Context and experience in auditors materiality judgments, Auditing, A Journal of Practice and Theory, 3, pp. 54-73. 
Kyte, R. (2007) Balancing rights with responsibilities: Looking for the global drivers of materiality in corporate social responsibility and the voluntary initiatives that develp and support them, American University International law Review, 23 (3), pp. 559-576.

Laughlin, R. C. (1991). Environmental disturbances and organizational transitions and transformations: some alternative models, Organization studies, 12(2), pp. 209-232.

Laughlin, R., Broadbent, J., \& Willig-Atherton, H. (1994). Recent financial and administrative changes in GP practices in the UK: initial experiences and effects, Accounting, Auditing \& Accountability Journal, 7(3), pp. 96-124.

Law, J. and Mol, (1995) Notes on materiality and sociality, The Sociological Review, 43(2), pp. 274-294.

Lee, T. A. (1984) Materiality: A Review and Analysis of Its Reporting Significance And Auditing Implications, Auditing Practices Committee.

Lincoln, Y.S. and Guba, E.G. (1985) Naturalistic Inquiry, Thousand Oaks CA: Sage.

Lounsbury, M., Ventresca, M. and Hirsch, P (2003) Social movements, field frames and industry emergence: a cultural-political perspective on US recycling, SocioEconomic Review, 1, pp. 71-104.

Lounsbury, M. (2007) A tale of two cities: Competing logics and practice in the professionalization of mutual funds, Academy of Management Journal, 50(2), pp. 289-307.

Lounsbury, M. (2008) Institutional rationality and practice variation: new directions in the institutional analysis of practice, Accounting Organizations and Society, 33, pp. 349-361.

Lukka, K. and Modell, S. (2010) Validation in interpretive management accounting research, Accounting Organizations and Society, 35, 462-477.

Malsch, B. and Gendron, Y. (2013) Retheorising change: Institutional experimentation and the struggle for domination in the field of public accounting, Journal of Management Studies, 50 (5), pp. 870-899.

Messier, W. E, Jr. (1983) The effect of experience and firm type of materiality/disclosure judgments, Journal of Accounting Research, 21(2), pp. 611-618. 
Messier, W.F. Jr., Martinov-Bennie N. and Eilifsen, A. (2005) A Review and Integration of Empirical Research on Materiality: Two Decades Later, Auditing, 24(2), pp. 153.

O’Dwyer, (2002) Managerial perceptions of corporate social disclosure: An Irish story, Accounting, Auditing \& Accountability Journal, 15 (3), pp.406 - 436

O'Dwyer, B. and Owen D. L. (2005) Assurance Statement Practice in Environmental, Social and Sustainability Reporting: A Critical Evaluation, British Accounting Review, 37, pp. 205-229.

O'Dwyer, B. and Owen D. L. (2007) Seeking Stakeholder centric Sustainability Assurance: An Examination of Recent Sustainability assurance Practice, The Journal of Corporate citizenship, 25, pp. 77-94.

Parker, L. (2005) Social and environmental accountability research: A view from the commentary box, Accounting, Auditing and Accountability Journal, 18(6), pp. 842860 .

Power, M. (1997) The Audit Society: Rituals of Verification, Oxford University Press, Oxford, UK.

Reay, T., \& Hinings, C. R. (2009) Managing the rivalry of competing institutional logics, Organization Studies, 30(6), pp. 629-652.

Richards, L. (2009) Handling Qualitative Data: A Practical Guide, $2^{\text {nd }}$ Edn., London: Sage.

Rutherford B. (2007) Financial reporting in the UK. A history of the financial accounting standards committee, Routledge Historical Perspectives in Accounting. SEC (1933) Regulation SX Rule 3-06.

Statement of Financial Accounting Concepts No. 2 (2008) Qualitative Characteristics of Accounting Information, Original Pronouncements, Issued May 1980, As Amended, Financial Accounting Standards Board.

Solomon, J.F. (2013) Corporate Governance and Accountability, John Wiley and Sons Inc.

Solomon, J.F and Edgley, C. (2008) The abandoned mandatory OFR: a lost opportunity for SER, Social Responsibility Journal, 4(3), pp. 324-348. 
Suddaby, R., Gendron, Y. and Lam, H. (2009) The organizational context of professionalism in accounting, Accounting, Organizations and Society, 34 (3-4), pp. 428-432.

Suddaby, R., and Greenwood, R. (2005). Rhetorical strategies of legitimacy, Administrative science quarterly, 50(1), pp. 35-67

SustainAbility (2004) Issue Brief 6, March 2004.

Thornton P. H. (2004) Markets from culture: Institutional logics and organizational logic decisions in higher education publishing, Stanford University Press, Stanford, CA.

Thornton, P., Ocasio, W. and Lounsbury, M. (2012) The Institutional Logics Perspective: A new Approach to Culture, Structure and Process, Oxford University Press: Oxford.

Tolbert, P. S., \& Zucker, L. G. (1983) Institutional sources of change in the formal structure of organizations: The diffusion of civil service reform, Administrative Science Quarterly, pp. 28, 22-39.

Turley, S. and Cooper, M. (1991) Auditing in the United Kingdom, Prentice-Hall International, Englewood Cliffs, NJ, 1991, pp. 70-81.

Wright, S. and Wright, A.M. (1997) The effect of industry experience on hypothesis generation and audit planning decisions, Behavioural Research in Accounting, 9, pp. 273-294. 
TABLE 1 Definitions of Materiality in SER Guidance

\begin{tabular}{|c|c|c|}
\hline Organisation & Description & $\begin{array}{l}\text { Definitions of SER Materiality in Guidance } \\
\text { Definition }\end{array}$ \\
\hline $\begin{array}{l}\text { International } \\
\text { Federation of } \\
\text { Accountants } \\
\text { (IFAC) }\end{array}$ & $\begin{array}{l}\text { The global } \\
\text { organisation for the } \\
\text { accountancy } \\
\text { profession. }\end{array}$ & $\begin{array}{l}\text { - Misstatements, including omissions, are considered } \\
\text { to be material if they could reasonably be expected } \\
\text { to influence the economic decisions of users taken } \\
\text { on the basis of the financial statements; } \\
\text { - Judgments about materiality are made in light of } \\
\text { surrounding circumstances. } \\
\text { - Judgments about matters that are material to users } \\
\text { of the financial statements are based on a } \\
\text { consideration of the common financial information } \\
\text { needs of users as a group. } \\
\text { (IFAC, 2010, ISA 320, p. 314). }\end{array}$ \\
\hline AccountAbility & $\begin{array}{l}\text { A non-profit global, } \\
\text { consultancy } \\
\text { organisation. } \\
\text { A multi-stakeholder } \\
\text { network. } \\
\text { Promotes } \\
\text { accountability in } \\
\text { reporting. }\end{array}$ & $\begin{array}{l}\text { Materiality determines the relevance and } \\
\text { significance of an issue to an organisation and its } \\
\text { stakeholders. } \\
\text { - A material issue influences the decisions, actions } \\
\text { and performance of an organisation or its } \\
\text { stakeholders. } \\
\text { - Stakeholders need to know which material issues } \\
\text { are relevant to the sustainability performance of } \\
\text { the organisation. } \\
\text { (AccountAbility, 2008b, p. 12). }\end{array}$ \\
\hline $\begin{array}{l}\text { The Global } \\
\text { Reporting } \\
\text { Initiative (GRI) }\end{array}$ & $\begin{array}{l}\text { A worldwide } \\
\text { stakeholder network } \\
\text { of experts. } \\
\text { The GRI guidelines } \\
\text { focus on standard } \\
\text { disclosures in three } \\
\text { reporting categories } \\
\text { (economic, social and } \\
\text { environmental). }\end{array}$ & $\begin{array}{l}\text { - The information in a report should cover topics } \\
\text { and indicators that reflect the organization's } \\
\text { significant economic, environmental, and social } \\
\text { impacts. } \\
\text { - Materiality is not limited to topics that have a } \\
\text { significant financial impact on the organization. It } \\
\text { considers wider impacts that would substantively } \\
\text { influence the assessments and decisions of } \\
\text { stakeholders. } \\
\text { - The concept of a threshold is important in } \\
\text { sustainability reporting. } \\
\text { GRI 3, 2000-2006, p.8). }\end{array}$ \\
\hline
\end{tabular}

"Materiality is the threshold at which an issue or indicator becomes sufficiently important that it should be reported. Beyond this threshold, not all material topics will be of equal importance and the emphasis within a report should reflect the relative priority of these material topics and indicators" (GRI, 2002, p. 9). 


\section{APPENDIX 1}

\section{Interview Questions}

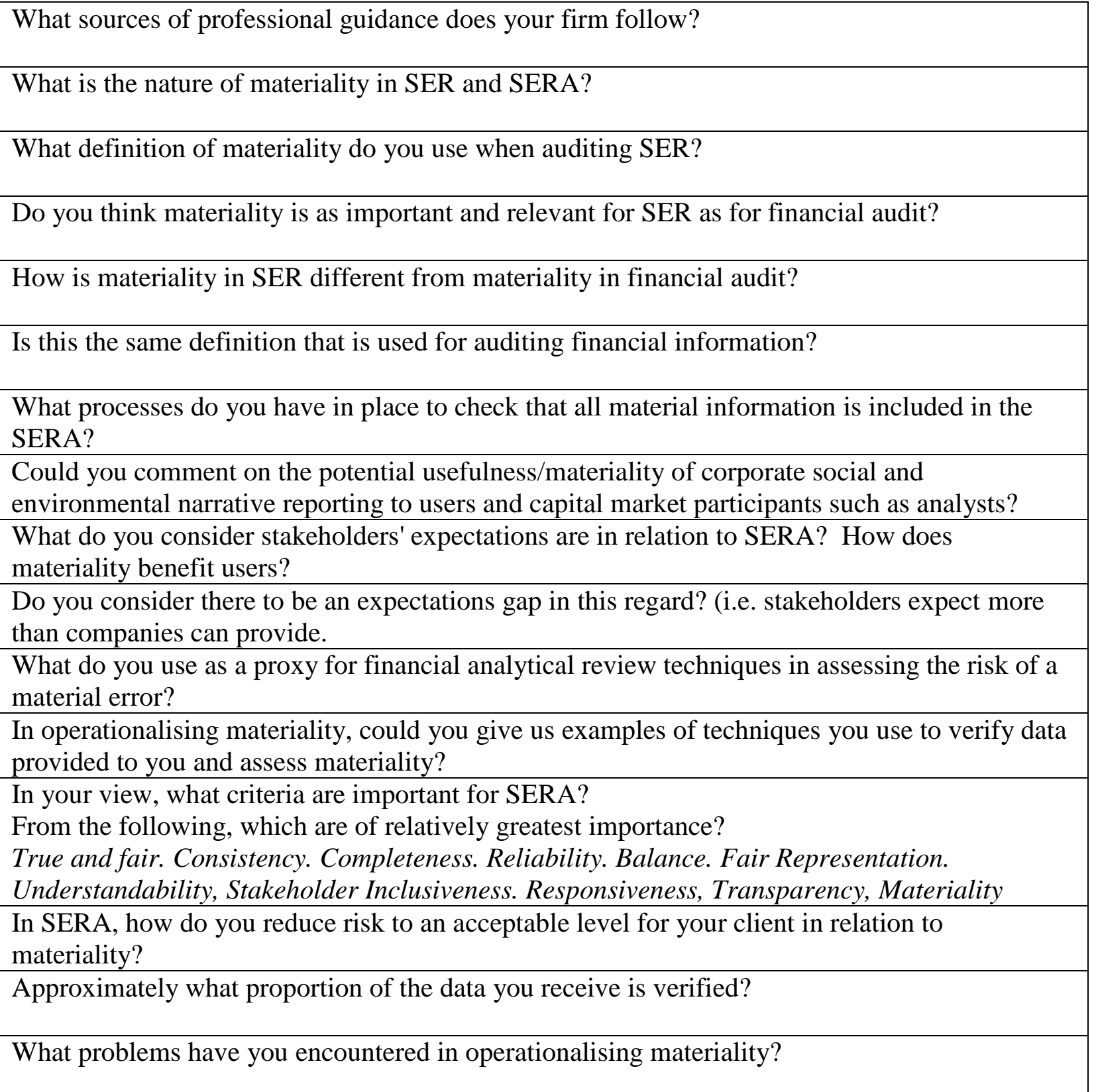


Have you developed firm specific guidance on materiality?

Is management capture of materiality potentially a problem?

Is there any inter-relationship between materiality in SER and financial audit?

How do you identify material issues for key stakeholder groups 